\title{
PENGARUH SENAM REMATIK TERHADAP INTENSITAS NYERI SENDI PADA PENDERITA OSTEOARTHRITIS
}

\author{
Sri Wahyuningsih ${ }^{1}$, Erwin ${ }^{2}$, Sofiana Nurchayati ${ }^{3}$ \\ ${ }^{1,2,3}$ Fakultas Keperawatan Universitas Riau Jalan Pattimura No 9 Gedung G Pekanbaru Riau \\ Kode Pos 28131 Indonesia \\ Email:wn398032@gmail.com
}

\begin{abstract}
Abstrak
Seiring dengan meningkatnya usia maka akan terjadi perubahan pada tubuh, keadaan demikian dapat berdampak pada sistem moskuloskeletal dan jaringan yang lain yang dapat menyebabkan penyakit osteoarthritis. Salah satu tanda dan gejala yang dapat ditemukan pada osteoarthritis adanya rasa nyeri pada sendi. Terapi alternatif yang dapat digunakan untuk mengurangi rasa nyeri akibat osteoarthritis yaitu dengan senam rematik. Tujuan dari penelitian ini adalah untuk mengetahui pengaruh senam rematik terhadap intensitas nyeri pada penderita osteoarthritis. Desain penelitian yang digunakan adalah quasy experiment. Sampel penelitian berjumlah 34 orang terdiri dari 17 orang kelompok eksperimen dan 17 orang kelompok kontrol yang diambil melalui teknik purposive sampling dan dipilih berdasarkan kriteria inklusi yaitu pasien rawat jalan terdiagnosa osteoarthritis tanpa komplikasi, berusia 26-46 tahun. Instrumen yang digunakan adalah lembar observasi tentang skala nyeri pre dan post test. Analisis data dengan univariat dan bivariat menggunakan uji t dependent, uji $\mathrm{t}$ independent, dan uji Mann Whitney, diperoleh hasil $p$ value $=0,000<\alpha$ $(0,05)$. Didapatkan hasil bahwa senam rematik berpengaruh dalam penurunan intensitas nyeri sendi pada penderita osteoarthritis Hasil penelitian ini diharapkan dapat dijadikan salah satu intervensi keperawatan untuk menurunkan intensitas nyeri sendi di masyarakat.
\end{abstract}

Kata Kunci : Intensitas nyeri, osteoarthritis, senam rematik

\begin{abstract}
In line with increasing age changes in the body will occur, such conditions can have an impact on the musculoskeletal system and other tissues that can cause osteoarthritis. One of the signs and symptoms that can be found in osteoarthritis is pain in the joints. One of alternative therapies that can be used to reduce pain due to osteoarthritis is rheumatic gymnastics. The purpose of this study was to determine the effect of rheumatic gymnastics on pain intensity in patients with osteoarthritis. The design used in this study is quasy experiment. The sample of this stdy amounted to 34 people consisting of 17 experimental groups and 17 control groups taken through purposive sampling technique and selected based on inclusion criteria, that were patients diagnosed with osteoarthritis without complications aged 26-46 years. The instrument used was the observation sheet about the scale of pain pre and post test. Data analysis with univariate and bivariate using dependent $t$ test, independent $t$ test, and mann whitney test, obtained the results of $p$ value $=$ $0,000<\alpha(0,05)$. The results showed that rheumatic gymnastics has an effect on decreasing the intensity of joint pain in patients with osteoarthritis. The results of this study are expected to be one of nursing interventions to reduce pain intensity of joint pain in the community.
\end{abstract}

Keywords : Osteoarthritis, pain intensity, rheumatic gymnastics

\section{PENDAHULUAN}

Osteoarthritis merupakan penyebab utama dari nyeri muskuloskeletal yang dapat mengakibatkan hilangnya pergerakan sendi. Osteoarthritis oleh American College of Rheumatology diartikan sebagai kondisi dimana terdapat gejala kecacatan pada integritas tulang rawan. Osteoarthritis biasanya mengenai sendi penopang berat badan (weight bearing) misalnya pada panggul, lutut, vertebra, dan dan dapat 
Sri Wahyuningsih, Erwin, dan Sofiana Nurchayati, Pengaruh Senam Rematik terhadap Intensitas Nyeri pada Penderita Osteoarthritis

mengenai bahu, sendi-sendi ijari tangan, dan pergelangan kaki (Carlos, 2013).

Prevalensi osteoarthritis berdasarkan Osteoarthritis Research Society Internasional (OARSI) (2016) mengalami peningkatan sebanyak $73 \%$ di tahun 2013 dan menempati peringkat sebagai kondisi ketiga yang paling cepat meningkat terkait dengan kecacatan dibelakang demensia dan diabetes melitus. Data dari hasil dari Riset Kesehatan Dasar (RISKESDAS) didapatkan bahwa terdapat penurunan prevalensi penyakit sendi pada usia $>15$ tahun dari 11,9\% di tahun 2013 menjadi 7,3\% ditahun 2018, sedangkan prevalensi di Riau tidak mengalami perubahan dari tahun 2013 hingga tahun 2018 yaitu sebesar 7,1\% (Kementrian Kesehatan, 2018).

Tanda dan gejala yang dapat dijumpai pada penderita osteoarthritis seperti kekakuan yang terjadi pada pagi hari umumnya 15 menit atau lebih karena perubahan dalam sendi, terjadi pembesaran pada sendi (deformitas), perubahan gaya berjalan, biasanya juga terdapat tanda-tanda terjadinya peradangan pada sendi (nyeri tekan, gangguan gerak, rasa hangat yang merata dan warna kemerahan), dan biasanya nyeri akan bertambah dengan aktivitas, membaik dengan istirahat. Rasa nyeri pada sendi dapat disebabkan karena pergerakan atau menahan beban berat karena terdapat perubahan pada bentuk sendi (Digiulio, Jackson \& Keogh, 2014).

Salah satu terapi non farmakologis yang dapat digunakan untuk mengatasi nyeri pada penderita osteoarthritis yaitu dengan senam rematik. Senam rematik merupakan suatu metode yang baik untuk pencegahan dan meringankan gejala-gejala serta dapat berfungsi sebagai terapi tambahan. Senam rematik merupakan senam yang berfokus pada mempertahankan lingkup ruang gerak sendi secara maksimal. Salah satu tujuan dari senam rematik ini yaitu untuk mengurangi nyeri sendi dan menjaga keseimbangan jasmani pada penderita osteoarthritis (Heri, 2014).

Berdasarkan studi pendahuluan yang telah dilakukan di Puskesmas Lima Puluh Kota Pekabaru, didapatkan bahwa jumlah penderita osteoarthritis sebanyak 1.681 orang pada tahun 2017. Penyakit osteoarthritis terletak pada urutan ke-3 dari 10 penyakit terbesar di wilayah kerja Puskesmas Lima Puluh Kota Pekanbaru. Hasil wawancara yang dilakukan pada 7 orang penderita osteoarthritis yaitu, penderita mengeluhkan adanya nyeri sendi dan kesulitan untuk bergerak. Salah satu cara penderita untuk mengatasi nyeri tersebut yaitu dengan menggunakan balsem ataupun minyak kayu putih dan mengkonsumsi obat-obatan farmakologis, belum ada tindakan non farmakologis yang dilakukan untuk mengatasi nyeri sendi tersebut. Penelitian ini bertujuan untuk mengetahui pengaruh senam rematik terhadap intensitas nyeri pada penderita osteoarthritis. 


\section{METODE PENELITIAN}

Penelitian dilakukan di wilayah kerja Puskesmas Lima Puluh Kota Pekanbaru yang dimulai dari bulan April sampai Mei 2019. Penelitian ini merupakan penelitian kuantitatif yang menggunakan desain penelitian Quasy Experiment dengan kelompok eksperimen dan kelompok kontrol dengan dilakukan pre test dan post test.

Populasi dalam penelitian ini adalah seluruh penderita osteoarthritis yang berada dalam cakupan wilayah kerja Puskesmas Lima Puluh Kota Pekanbaru. Pengambilan sampel menggunakan teknik pusrposive sampling dengan 34 responden. Kriteria inklusi untuk sampel dalam penelitian ini adalah pasien rawat jalan terdiagnosa osteoarthritis tanpa komplikasi, berusia 26 hingga 46 tahun, berdomisili di wilayah kerja Puskesmas Lima Puluh Kota Pekanbaru, bersedia menjadi objek penelitian, dan merasakan nyeri.

Senam rematik ini dilakukan sebanyak 2x dalam seminggu, dengan durasi $1 \mathrm{x}$ senam selama 30 menit. Senam dilakukan setiap pukul 08.00 WIB selama 2 hari berturut-turut.

Alat pengumpul data yang digunakan dalam penelitian ini adalah lembar observasi yang berisi mengenai data demografi, pengukuran intensitats nyeri dengan menggunakan Numeric Rating Scale (NRS), dan tabel ketepatan gerakan senam rematik.

Analisis data dilakukan dengan menggunakan program komputer. Analisis univariat menampilkan distribusi frekuensi dan persentase dari karakteristik responden meliputi umur, jenis kelamin, pendidikan, pekerjaan, serta rata-rata intensitas nyeri pada penderita osteoarthritis. Analisis bivariat untuk mengetahui perbandingan intensitas nyeri pre dan post test pada kelompok eksperimen dan kelompok konrol adalah dengan uji dependent sample t tes. Perbedaan intensitas nyeri sendi pre test dan post test pada kelmpok eksperimen dan kelompok kontrol dilakukan dengan uji independent sample $t$ test. Derajat kemaknaan $(\alpha)$ yang digunakan dalam penelitian ini adalah 0,05.

\section{HASIL PENELITIAN}

\section{Analisis Univariat}

Tabel 1

Distribusi karakteristik responden dan uji homogenitas

\begin{tabular}{|c|c|c|c|c|c|c|c|}
\hline \multirow[t]{2}{*}{$\begin{array}{c}\text { Karakteri } \\
\text { stik }\end{array}$} & \multicolumn{2}{|c|}{$\begin{array}{l}\text { Kelompok } \\
\text { Eksperime } \\
\mathrm{n} \\
(\mathrm{n}=17)\end{array}$} & \multicolumn{2}{|c|}{$\begin{array}{l}\text { Kelompo } \\
\text { k Kontrol } \\
(\mathrm{n}=17)\end{array}$} & \multicolumn{2}{|c|}{ Jumlah } & \multirow[t]{2}{*}{$\begin{array}{l}p \\
\text { valu } \\
e\end{array}$} \\
\hline & $\mathrm{N}$ & $\%$ & $\mathrm{n}$ & $\%$ & $\mathrm{n}$ & $\%$ & \\
\hline \multicolumn{8}{|l|}{ Umur } \\
\hline $\begin{array}{l}\text { Dewasa } \\
\text { awal (26- } \\
35)\end{array}$ & 7 & 41,2 & 7 & 41,2 & 14 & 41,1 & \multirow[t]{2}{*}{$\begin{array}{c}0,97 \\
3\end{array}$} \\
\hline $\begin{array}{l}\text { Dewasa } \\
\text { akhir } \\
(36-46) \\
\end{array}$ & 10 & 58,8 & 10 & 58,8 & 20 & 58,9 & \\
\hline \multicolumn{8}{|l|}{ Jenis } \\
\hline $\begin{array}{l}\text { Perempu } \\
\text { an }\end{array}$ & 11 & 64,7 & 13 & 76,5 & 24 & 70,6 & \multirow[t]{2}{*}{$\begin{array}{c}0,15 \\
3\end{array}$} \\
\hline $\begin{array}{l}\text { Laki- } \\
\text { Laki }\end{array}$ & 6 & 35,3 & 4 & 23,5 & 10 & 29,4 & \\
\hline \multicolumn{8}{|l|}{$\begin{array}{l}\text { Pendidik } \\
\text { an }\end{array}$} \\
\hline $\begin{array}{l}\text { Tidak } \\
\text { Sekolah }\end{array}$ & 0 & 00,0 & 0 & 00,0 & 0 & 00,0 & \multirow{5}{*}{$\begin{array}{c}0,31 \\
7\end{array}$} \\
\hline $\mathrm{SD}$ & 0 & 00,0 & 0 & 00,0 & 0 & 00,0 & \\
\hline SMP & 1 & 5,9 & 1 & 5,9 & 2 & 5,9 & \\
\hline SMA & 12 & 70,6 & 10 & 58,8 & 22 & 64,7 & \\
\hline PT & 4 & 23,5 & 6 & 35,3 & 10 & 29,4 & \\
\hline Pekerjaan & & & & & & & 0,34 \\
\hline $\begin{array}{l}\text { IRT } \\
\text { Wiraswasta }\end{array}$ & $\begin{array}{l}7 \\
7\end{array}$ & $\begin{array}{l}41,2 \\
41,2\end{array}$ & $\begin{array}{l}6 \\
5\end{array}$ & $\begin{array}{l}35,3 \\
29,4\end{array}$ & $\begin{array}{l}13 \\
12\end{array}$ & $\begin{array}{l}38,2 \\
35,3\end{array}$ & 5 \\
\hline
\end{tabular}


Sri Wahyuningsih, Erwin, dan Sofiana Nurchayati, Pengaruh Senam Rematik terhadap Intensitas Nyeri pada Penderita Osteoarthritis

\begin{tabular}{lrrrrrr} 
PNS & 3 & 17,6 & 5 & 29,4 & 8 & 23,5 \\
Tidak & & 00,0 & 1 & 5,9 & 1 & 2,9 \\
Bekerja & 0 & & & & & \\
\hline
\end{tabular}

Berdasarkan tabel 1 diketahui bahwa terdapat 34 responden yang diteliti, distribusi responden menurut umur yaitu 36-46 tahun sebanyak 20 responden $(58,9 \%)$, menurut jenis kelamin sebagian besar berjenis kelamin perempuan yaitu sebanyak 24 responden $(70,6 \%)$, menurut pendidikan terakhir sebagian besar SMA yaitu sebanyak 22 responden $(64,7 \%)$, menurut pekerjaan sebagian besar adalah Ibu Rumah Tangga (IRT) yaitu sebanyak 13 responden $(38,2 \%)$.

Tabel 2

Rata-rata intensitas nyeri pre test dan post test responden pada kelompok eksperimen dan kelompok kontrol

\begin{tabular}{lcccc}
\hline \multicolumn{1}{c}{ Variabel } & Mean & SD & Min & Max \\
\hline $\begin{array}{l}\text { Kelompok } \\
\text { Eksperimen }\end{array}$ & & & & \\
Pre test & 5,12 & 2,058 & 2,0 & 9,0 \\
$\begin{array}{l}\text { Post test } \\
\text { Selisih }\end{array}$ & 3,91 & 1,914 & 1,0 & 8,0 \\
\hline Kelompok & & & & \\
Kontrol & & & & \\
Pre test & 3,70 & 2,410 & 2,0 & 9,0 \\
Post test & 5,02 & 2,110 & 2,0 & 8,5 \\
Selisih & $-0,08$ & 0,667 & $-1,0$ & 1,5 \\
\hline
\end{tabular}

Tabel 2 pada kelompok kelompok eksperimen nilai rata-rata intensitas nyeri responden sebelum diberikan intervensi yaitu 5,12 dengan standar deviasi 2,058, dan setelah diberikan intervensi nilai rata-rata mean yaitu 3,91 dengan standar deviasi 1,914, nilai selisih mean intensitas nyeri pre test yaitu 1,20 dengan standar deviasi 0,560.

Nilai rata-rata intensitas nyeri pada kelompok kontrol tanpa mendapatkan intervensi yaitu pre test sebesar 3,70 dengan standar deviasi 2,410 dan post test sebesar 5,029 dengan standar deviasi 2,110, nilai selisih mean intensitas nyeri pre test dan pos test -0,008 dengan standar deviasi 0,667.

\section{Analisis Bivariat}

Analisis bivariat digunakan untuk menilai perbedaan intensitas nyeri responden pada kelompok eksperimen dan kelompok kontrol pada penderita osteoarthritis. Hasil penelitian akan dikatakan berpengaruh jika $p$ value $<\alpha$ $(0,05)$. Uji normalitas dilakukan sebelum data dilakukan uji statistik untuk melihat bahwa data terdistribusi normal dan layak untuk diujikan.

Tabel 3

Uji normalitas data intensitas nyeri pre test dan post test pada keloompok eksperimen dan kelompok kontrol

\begin{tabular}{lcc}
\hline Variabel & $\mathrm{N}$ & $p$ value \\
\hline $\begin{array}{l}\text { Kelompok } \\
\text { eksperimen }\end{array}$ & & \\
$\begin{array}{l}\text { Pre test } \\
\text { Post test }\end{array}$ & 17 & 0,682 \\
\hline Kelompok kontrol & 17 & 0,097 \\
Pre test & 17 & 0,482 \\
Post test & 17 & 0,175 \\
\hline Selisih pre test dan & & \\
post test & & \\
Eksperimen & 17 & 0,011 \\
Kontrol & 17 & 0,037 \\
\hline
\end{tabular}

Tabel 3 menunjukkan menunjukkan uji normalitas data dari uji Shapiro-Wilk didapatkan intensitas nyeri pada kelompok eksperimen dan kelompok kontrol data terdistribusi normal dengan $p$ value pre test sebesar $0,682>(\alpha=0,05)$ sedangkan $p$ value post test $0,097>(\alpha=0,05)$. Pada kelompok 
Jurnal Ners Indonesia, Vol.11 No.1, September 2020

kontrol data intensitas nyeri terdistribusi normal dengan nilai pre test dan post test pada uji normalitas Shapiro-Wilk didapatkan $p$ value $0,482 \& 0,175>(\alpha=0,05)$. Selisih antara intensitas nyeri pre test dan post test pada kelompok eksperimen dan kelompok kontrol tidak terdistribusi normal dengan $p$ value $0,011 \& 0,037>(\alpha=0,05)$.

Tabel 4

Perbedaan intensitas nyeri pre test dan post test pada kelompok eksperimen dan kelompok kontrol

\begin{tabular}{lccc}
\hline \multirow{2}{*}{ Kelompok } & \multicolumn{3}{c}{ Pre test } \\
\cline { 2 - 3 } & Mean & SD & $\begin{array}{c}p \\
\text { value }\end{array}$ \\
\hline Eksperimen & 5,12 & 2,058 & 0,820 \\
\hline Kontrol & 4,94 & 2,410 & \\
\hline
\end{tabular}

Tabel 4 menunjukkan intensitas nyeri pre test dan post test pada kelompok eksperimen dan kelompok kontrol. Hasil uji statistik dengan menggunakan uji Mann Whitney didapatkan hasil bahwa tidak terdapat perbedaan yang signifikan yaitu $p$ value 0,820 $>\alpha(0,05)$. Hal ini menunjukkan bahwa tidak ada perbedaan yang signifikan antara intensitas nyeri pre test pada kelompok eksperimen dan intensitas nyeri pada pre test pada kelompok kontrol

Tabel 5

Pengaruh pemberian senam rematik terhadap intensitas nyeri pada kelompok eksperimen dan kelompok kontrol

\begin{tabular}{lccc}
\hline \multicolumn{1}{c}{$\begin{array}{c}\text { Selisih } \\
\text { Intensitas } \\
\text { Nyeri }\end{array}$} & Mean & SD & $\begin{array}{c}p \\
\text { value }\end{array}$ \\
\cline { 2 - 3 } & & 0,5607 & \\
\hline $\begin{array}{l}\text { kelompok } \\
\text { eksperimen }\end{array}$ & 24,59 & 0,000 \\
\hline $\begin{array}{l}\text { kelompok } \\
\text { kontrol }\end{array}$ & 10,41 & 0,6670 & \\
\hline
\end{tabular}

Tabel 5 menunjukkan selisih intensitas nyeri pre test dan post test pada kelompok eksperimen dan kelompok kontrol dengan menggunakan uji statistik Mann Whitney didapatkan perbedaan yang signifikan yaitu $p$ value $0,000<\alpha(0,005)$. Hal ini menunjukkan bahwa hipotesis nol ditolak, disimpulkan senam rematik berpengaruh terhadap penurunan intensitas nyeri pada penderita osteoarthritis.

Tabel 6

Perbedaan intensitas nyeri pre test dan post test pada kelompok eksperimen setelah melakukan senam rematik

\begin{tabular}{lcccc}
\hline Variabel & $\mathrm{N}$ & Mean & $S D$ & $\begin{array}{c}p \\
\text { value }\end{array}$ \\
\cline { 1 - 4 } Pre test & 17 & 5,12 & 2,058 & 0,000 \\
\hline Post test & 17 & 3,91 & 1,914 & \\
\hline
\end{tabular}

Berdasarkan tabel 6 hasil uji statistik dengan menggunakan uji $t$ dependent didapatkan bahwa kelompok eksperimen memiliki perbedaan yang bermakna pada penurunan intensitas nyeri pre test dan post test dengan hasil yang signifikan yaitu $p$ value $0,000<\alpha(0,05)$.

Tabel 7

Perbedaan intensitas nyeri pre test dan post test pada kelompok kontrol tanpa melakukan senam rematik

\begin{tabular}{ccccc}
\hline Variabel & $\mathrm{N}$ & Mean & SD & $\begin{array}{c}p \\
\text { value }\end{array}$ \\
\cline { 1 - 4 } Pre test & 17 & & & \\
& & 4,94 & 2,410 & 0,593 \\
\hline Post test & 17 & 5,029 & 2,1100 & \\
\hline
\end{tabular}

Berdasarkan tabel 7 didapatkan hasil bahwa pada kelompok kontrol tidak ada perbedaan yang bermakna pada penurunan intensitas nyeri pre test dan post test dengan hasil yaitu $p$ value $0,593>\alpha(0,05)$. 
Sri Wahyuningsih, Erwin, dan Sofiana Nurchayati, Pengaruh Senam Rematik terhadap Intensitas Nyeri pada Penderita Osteoarthritis

\section{PEMBAHASAN}

\section{Analisis Univariat}

a. Umur

Berdasarkan kriteria inklusi peneliti menetapkan umur responden dengan rentang 26-46 tahun. Peneliti membagi usia responden menjadi 2 kelompok berdasarkan pembagian umur menurut Depkes (2009) yaitu dewasa awal (26-35 tahun), dan dewasa akhir (36-46 tahun).

Marlina (2015) mengatakan bahwa bertambahnya usia akan terjadi pengurangan volume/ isi tulang rawan, penurunan kekuatan otot, kehilangan proprioseptif, perubahan degeneratif pada meniskus dan ligamen sendi serta pengapuran jaringan sendi. Akibat dari perubahan yaitu mengakibatkan ruang sendi menyempit sehingga dapat menyebabkan gesekan antara ujung tulang, hal inilah yang dapat menyebabkan nyeri. Selain itu, usia/tingkat perkembangan berpengaruh terhadap persepsi dan ekspresi nyeri.

\section{b. Jenis Kelamin}

Hasil penelitian didapatkan sebagian besar responden berjenis kelamin perempuan yaitu sebanyak 24 responden (70,6\%). Penelitian Fransen et al., (2011) menunjukkan bahwa angka kejadian osteoarthritis lebih besar terjadi pada perempuan dikarenakan terjadinya menopause pada perempuan yang dapat menyebabkan penurunan pada kadar hormon estrogen secara drastis, sementara itu pada laki-laki kadar hormon estrogen menurun secara perlahan. Hormon estrogen ini berperan dalam pembentukan tulang. Selain itu, perempuan memiliki peluang peningkatan Indeks Masa Tubuh (IMT) lebih besar.

\section{c. Pendidikan}

Hasil penelitian didapatkan karakteristik responden menurut pendidikan mayoritas adalah SMA yaitu sebanyak 22 responden $(64,7 \%)$.

Sutrisno (2011) mengemukakan bahwa pendidikan adalah salah satu faktor yang dapat mempengaruhi pengetahuan seseorang, semakin tinggi pendidikan seseorang, maka akan semakin mudah pula dalam menerima informasi yang pada akhirnya makin banyak pula pengetahuan yang mereka miliki. Sebaliknya jika pendidikan rendah, maka akan menghambat perkembangan sikap seseorang terhadap penerimaan informasi dan nilai-nilai yang baru diperkenalkan.

\section{d. Pekerjaan}

Karakteristik pekerjaan kelompok responden eksperimen dan kontrol mayoritasnya adalah IRT (Ibu Rumah Tangga) yaitu sebanyak 13 responden $(38,2 \%)$.

Dengan keberadaan nyeri akibat dari osteoarthritis ini, maka biasanya penderita akan membatasi pergerakan pada daerah yang mengalami nyeri (Sharma \& Berenbaum, 2013). Pembatasan gerak pada sendi yang dilakukan dapat menyebabkan kekakuan atau atropi otot sendi yang lama kelamaan dapat menghentikan secara permanen fungsional sendi tersebut (Sitinjak et al, 2016). 


\section{Analisis Bivariat}

a. Perbandingan intensitas nyeri sesudah melakukan senam rematik pada kelompok eksperimen dan kelompok kontrol

Hasil uji Mann Whitney didapatkan hasil mean selisih intensitas yeri pre test dan post test pada kelompok eksperimen adalah 24,59 dengan standar deviasi 0,5607, sedangkan pada kelompok kontrol nilai mean selisih intensitas nyeri pre test dan post test adalah 10,41 dengan standar deviasi 0,6670. Hasil uji statistik didapatkan $p$ value $0,000<\alpha$ $(0,05)$.

Jadi dapat disimpulkan bahwa ada perbedan yang signifikan pada intensitas nyeri antara kelompok eksperimen yang melakukan senam rematik dengan kelompok kontrol yang tidak melakukan senam rematik.

Adanya pengaruh senam rematik terhadap intensitas nyeri yaitu dikarenakan senam rematik merupakan senam ringan yang dapat berfungsi dalam mengatasi keluhankeluhan yang biasanya muncul pada penyakit osteoarthritis, misalnya kekakuan pada sendi, kelemahan dan ketegangan otot. Gerakan senam rematik ini dimaksudkan untuk meningkatkan kemampuan gerak, fungsi, kekuatan dan daya tahan otot (Suwarni et al, 2017).

b. Perbandingan intensitas nyeri sebelum dan sesudah melkaukan senam rematik pada kelompok eksperimen

Hasil uji dependent $t$ test didapatkan mean intensitas nyeri sebelum diberikannya intervensi yaitu 5,12 dengan standar deviasi 2,058, dan sesudah intervensi yaitu 3,912 dengan standar deviasi 1,9141. Hasil analisis data diperoleh $p$ value $0,000<\alpha(0,05)$. Jadi dapat disimpulkan ada penurunan mean intensitas nyeri yang signifikan pada kelompok eksperimen.

Kuntaraf (2010) menyatakan bahwa senam rematik memiliki dampak psikologis langsung yaitu dapat membantu memberi perasaan santai, mengurangi ketegangan, dan meningkatkan perasaan senang karena saat senam kelenjar pituitari menambah produksi atau meningkatkan level beta-endorfin. Hal ini didukung oleh Nursalam dan Kurniawati (2014), selain produksi beta-endorfin, senam juga dapat meningkatkan aktivitas penyaluran saraf didalam otak yaitu peningkatan neurotransmiter parasimpatis (norepinephrine, dopamine, dan serotonin). Peningkatan konsentrasi beta-endorfin didalam darah dan saraf parasimpatis dapat menurunkan denyut jantung dan denyut nadi sehingga dapat menyebabkan nyeri yang memunculkan kekakuan sendi menjadi berkurang.

\section{c. Perbandingan intensitas nyeri sebelum dan sesudah melakukan senam rematik pada kelompok kontrol}

Uji statistik untuk kelompok kontrol yaitu uji dependent $t$ test didapatkan mean intensitas nyeri responden pre test yaitu 4,94 dengan standar deviasi 2,410 dan post test yaitu 5,029 dengan standar deviasi 2,1100. Hasil analisa data diperoleh $p$ value sebesar $0,593>\alpha(0,05)$. 
Sri Wahyuningsih, Erwin, dan Sofiana Nurchayati, Pengaruh Senam Rematik terhadap Intensitas Nyeri pada Penderita Osteoarthritis

Dri hasil tersebut dapat disimpulkan bahwa tidak ada perbedaan antara intensitasnyeri pre test dan post test pada kelompok kontrol sebelum ataupun sesudah melakukan senam rematik. Hal ini dikarenakan pada kelompok kontrol tidak melakukan senam rematik untuk membantu menurunkan intensiats nyeri pada penderita osteoarthritis.

\section{SIMPULAN}

Didapatkan hasil bahwa mayoritas yang menderita osteoarthritis adalah usia 3646 tahun $(58,9 \%)$, jenis kelamin perempuan (70,6\%), pendidikan terakhir SMA $(64,7 \%)$, dan pekerjaan IRT $(38,2 \%)$.

Penurunan intensitas nyeri pada penderita osteoarthritis setelah melakukan senam rematik yang dilakukan $2 \mathrm{x}$ dalam seminggu dengan durasi 30 menit dalam $1 x$ senam dengan hasil yang signifikan dengan $p$ value $0,000<\alpha(0,05)$.

\section{SARAN}

Hasil penelitian ini diharapkan dapat dijadikan referensi untuk penelitian selanjutnya tentang pengobatan alternatif dengan senam rematik pada penderita osteoarthritis. Saat melaksanakan penelitian, untuk faktor perancu yaitu aktifitas fisik dan psikologis agar dapat dikontrol dan dibahas lebih detail di pembahasan apakah terdapat perbedaan intensitas nyeri sendi dari faktor perancu untuk mengurangi bias.

\section{DAFTAR PUSTAKA}

Afnuhazi, R. (2018). Pengaruh Senam Rematik Terhadap Penurunan Nyeri Rematik Pada Lansia. Menara Ilmu, 7, 2-5.

Carlos, LJ. (2013). Training program. clinical medicine. Departement of Medicine, Division of Rheumatology and Immunology. University of Miami. Terjemahan Leonard M Miller. Editors Herbert S Diamond. 2013 School of Medicine USA

Depkes RI. (2009). Profil Kesehatan Indonesia. diperoleh pada tanggal 28 April 2019 dari www.depkes.go.id/resources/download /.../profil-kesehatan-indonesia-2009.pdf Dharma, K.K (2015). Metodologi penelitian keperawatan (panduan melaksanakan dan menerapkan hasil penelitian). Edisi revisi 2015. Jakarta: CV.Trans Info Media.

Digulio, M., Jackson, D., \& Keogh, J. (2014). Keperawatan medikal bedah (1 ed.). (A. Prabawati, Meidyna, Penyunt., \& D. Prabantini, Penerj.) Yogyakarta: Rapha Publishing.

Fransen, M., Bridgett, L., March, L., Hoy, D., Penserga, E., \& Brooks, P. (2011). The epidemiology of osteoarthritis in Asia. International Journal of Rheumatic Diseases, 14(2), p 113-121

Heri, K. (2014). Pengaruh Senam Rematik terhadap Nyeri Sendi pada Lansia di Panti Sosial Tresna Werdha Budimulia 04 Margaguna Jakarta Selatan. Jurnal Mahasiswa Program Keperawatan Universitas Esa Unggul, 1(1). h. 1-10

Kementerian Kesehatan. (2018). Hasil Utama Riskesdas 2018. Retrieved Januari 10, 2019, from http://www.depkes.go.id/resources/dow nload/info-

terkini/materi_rakorpop_2018/Hasil\% 20Riskesdas\%202018.pdf

Kuntaraf, J. (2010). Olahraga sumber kesehatan. Bandung: Advent Indonesia

Marlina, T. T. (2015). Efektifitas Latihan Lutut Terhadap Penurunan Intensitas Nyeri Pasien Osteoarthritis Lutut di 
Yogyakarta. Jurnal Keperawatan

Sriwijaya, 2, 45-46.

OARSI. (2016). Osteoarthritis Reserchn

Society

International. Retrieved Maret 28, 2019, from

https://www.oarsi.org/sites/default/files/docs/2

016/oarsi_white_paper_oa_serious_dis ease_121416_1.pdf

Sharma, L., \& Berenbaum, F. (2013).

Osteoarthritis: A companion to

rheumatology. Elsevier Health

Sciences.

Sitinjak, V. M., Hastuti, M. F., \& Nurfianti, A. (2016). Pengaruh Senam Rematik terhadap Perubahan Skala Nyeri Pada Lanjut Usia dengan Osteoarthritis Lutut. 4, 140-150.

Sutrisno, E. (2011). Manajemen sumber daya Manusia. Jakarta: Kencana.

Suwarni, A., Yani, I., \& Murtutik, L. (2017). Efektifitas Senam Rematik Terhadap Kemampuan Berjalan dengan Nyeri Sendi untuk Mencapai Hidup yang Sehat dan Sejahtera pada Lanjut Usia. Jurnal Ilmu Keperawatan Indonesia, 10, 3-9. 